\title{
Promoting Mucuna Beans Production for Soil Rehabilitation, Incomes, Food and Nutrition Security in Kenya
}

\author{
Mary Stella Wabwoba ${ }^{1 *}$ and Kenneth Mutoro ${ }^{2}$ \\ ${ }^{1}$ Licha Consultancy, Bungoma, Kenya Email.wabstella@yahoo.com \\ ${ }^{2} J o m o$ Kenyatta University of Agriculture and Technology, Department of Horticulture and Food Security, Nairobi, Kenya
}

*Corresponding author: Mary Stella Wabwoba, LICHA Consultancy, Bungoma, Kenya.

Received Date: September 03, 2019

Published Date: November 13, 2019

\begin{abstract}
This is a review paper of promotion of Mucuna (Mucuna pruriens) beans in western Kenya (Bungoma, Kakamega and Siaya counties). Mucuna is a leguminous plant grown in tropical woodlands. It is an emerging multiple use legume with the potential to restore soil structure, used as animal - feed, as well as food/nutrition security in households. Due to its many uses, it was promoted for adoption by farmers in western Kenya. Families in western part of Kenya were food insecure in terms of protein insufficiency, crop productivity was low due to infertile soils and had low incomes within households. The adoption of Mucuna growing would solve the mentioned problems. Farmers were mobilized to grow the beans, process for food and for sell to earn income. The maize yield intercropped with Mucuna doubled in subsequent years. Various recipes were developed, tasted and adopted. The raw beans and processed products earned household's income which improved livelihoods. The Mucuna beans production was therefore recommended for soil rehabilitation, income generation and for food and nutrition security within households.
\end{abstract}

Keywords: Mucuna beans; Soil rehabilitation; Incomes; Food and nutrition security

Abbreviations: GIZ: Deutsche Gesellschaft für Internationale Zusammenarbeit (GIZ) GmbH; CA: Conservation Agriculture; GOPA: Gesellschaft für Organization, Planung and Ausbildung; WHH: Welt Hunge Hilife; KALRO: Kenya Agriculture and Livestock Research Organization

\section{Introduction}

Mucuna (Mucuna-pruriens) beans is a genus of around 100 accepted species of climbing lianas (vines) and shrubs of the family Fabaceae and typically found in tropical woodlands. The plant has a potential for multiple uses. According to Food and Agriculture Organization [1], Mucuna has potential to restore soil as well as provide food. It is an emerging multiple-use leguminous crop [2] with high potential to enhance soil health and biodiversity. Mucuna has been grown in Kenya for purposes of rehabilitating deteriorated soils, animal feeds as well as human food. Farmers in Western Kenya (Bungoma, Kakamega and Siaya counties) have grown Mucuna beans as a Conservation Agriculture (CA) crop. This crop when grown, it prevents soil deterioration and rehabilitate the affected areas, meaning it has the potential to restore soil structure [1]. The Western Kenya counties in partnership with GIZ promoted the growing of Mucuna crop as a soil cover crop. A total of 325 (7500 individual farmers) farmer groups are actively involved in Mucuna production. On average 18,967 hectares of land were rehabilitated by growing Mucuna beans crop (Table 1). This explains why the beans have been promoted widely in these counties.

Table 1: Soil Project Indicator achievements- October 2018.

\begin{tabular}{|c|c|c|c|c|c|c|c|c|c|c|}
\hline \multirow{2}{*}{$\begin{array}{l}\text { Location } \\
\text { Output A } \\
\end{array}$} & \multicolumn{3}{|c|}{ Siaya } & \multicolumn{3}{|c|}{ Kakamega } & \multicolumn{3}{|c|}{ Bungoma } & \multirow{2}{*}{$\begin{array}{l}\text { Grand } \\
\text { Total }\end{array}$} \\
\hline & GOPA & WHH & Sub Total & GOPA & WHH & Sub Total & GOPA & WHH & Sub Total & \\
\hline \multirow{2}{*}{$\begin{array}{c}\text { On-Farm area } \\
\text { protected/ } \\
\text { rehabilitated }\end{array}$} & $\begin{array}{c}10,900 \\
\text { acres }\end{array}$ & 7,160 acres & $\begin{array}{l}18,060 \\
\text { acres }\end{array}$ & $\begin{array}{c}\text { 11,871 } \\
\text { acres }\end{array}$ & 5,866 acres & 17,737acre & $\begin{array}{c}10,940 \\
\text { acre }\end{array}$ & 681 acres & $\begin{array}{c}11621 \\
\text { acres }\end{array}$ & $\begin{array}{c}47,418 \\
\text { acre }\end{array}$ \\
\hline & 4360 ha & 2864 ha & 7,224 ha & 4,748 ha & 2,346 ha & 7,094 ha & 4,376 ha & 272 ha & 2298 ha & 18967 ha \\
\hline
\end{tabular}


Field reports indicated that crops grown on land that previously was under Mucuna or intercropped with it doubled yields. Accordingly, 50\% grain-yield increase was reported at demonstration farms in maize grown under conservation agriculture systems in Kakamega, Bungoma and Siaya counties that used the Mucuna bean as an intercrop or rotation crop [3]. Soil is the most valuable and widespread natural resource that supports agricultural-based livelihoods. Soil in Western Kenya is highly degraded due to inappropriate farming practices such as overreliance on mineral fertilizer, erosion and inadequate rotation. Productivity levels of many crop enterprises is below potential, while the yield trends have either remained constant or are on the decline. Additionally, the soils have sub optimal nitrogen, organic matter, and low $\mathrm{pH}$ [4]. To get higher yields, farmers have often resorted to applying more and more inorganic fertilizers, thus high cost of production and accelerated soil pollution [1].

Mucuna bean, like other legume seeds, contains anti-nutritional compounds such as phytate, polyphenols, protease inhibitors and aromatic amino acids that cause physiological and biochemical effects including decreased protein digestibility plus growth inhibition in animals [5]. A variety of processing techniques such as soaking, heat treatment (boiling and roasting), have been used to remove anti-nutritional compounds and hence improve bean nutritional value [6]. Mucuna bean contains a major antinutritional compound, a non-protein amino acid, 3,4-dihydroxy-Lphenylalanine (L-Dopa) which must be removed before utilization [7]. There was lack of useful data in the Counties showing the nutritive value, recipes, various products from Mucuna crop. There was need for an elaborated training to equip the lead farmers with sufficient knowledge to pass on to others. This approach was used to make Mucuna production sustainable, generate income for households and contribute towards reducing food insecurity cases among households.

\section{The Problem}

Households in Bungoma County are food insecure because many families take one meal a day and more specifically men were reported to be malnourished due to protein deficit in their diets [8,4]. Mucuna is rich in protein but cannot be utilized without processing due to the presence of anti-nutritional compounds such as phytate, polyphenols, protease inhibitors and aromatic amino acids that cause physiological and biochemical effects including decreased protein digestibility, growth inhibition in animals. Mucuna bean contains a major anti-nutritional compound, a non-protein amino acid, 3,4-dihydroxy-L-phenylalanine-L-Dopa [9]. Survey reports showed that, there was lack of useful data in the survey Counties to show the nutritive value, recipes, various products from Mucuna beans. The impact on the yield of crop intercropped with Mucuna beans was not established. Field reports revealed that farmers wished to utilize the Mucuna beans but lacked knowledge on how to process the beans into palatable forms [10]. Therefore, it was necessary for an elaborated training to equip the lead farmers with sufficient knowledge to pass on to others. This approach was used to make Mucuna production sustainable and would contribute towards reducing food insecurity cases among households.

\section{Objectives}

- To assess the impact of Mucuna as a cover crop on agricultural productivity of arable land while conserving the soil resources through innovative farming practices.

- To capacity build extension staff and farmers on how to process the beans to remove the Ant-nutritional Factors (L-Dopa and other anti-nutrients) and develop home grown recipes in combination with locally available foods to increase food security.

- To empower farmers with business skills to value add and market Mucuna products as an income generating activity (IGA) to increase incomes and improve livelihoods.

\section{Methodology}

The survey targeted agriculture extension officers and farmer groups and individuals growing Mucuna beans. To achieve the above objectives, First, the GIZ project staff from Bungoma, Kakamega and siaya Counties mobilized agricultural extension staff both from public and NGOs/organizations, who were involved in promotion of Mucuna as cover crop for conservation agriculture in the GIZ/GOPA Soil Protection and Rehabilitation programme, for purpose of this survey. The extension staff undertook a training for two days after which they each trained farmer within their wards on the same. Secondly, farmer groups from Bungoma, Kakamega and Siaya counties were mobilized and sensitised on growing of Mucuna beans as a cover crop to rehabilitate the degraded soils. Farmers were given Mucuna beans to grow on their farms as an intercrop with maize and the maize yields compared [3]. Thirdly, the lead farmers were trained on how to process the beans to remove anti-nutritional factors (ANF), developed recipes alongside locally available foods. The delivery methods of training involved presentations, cooking demonstrations and group discussions. Finally, farmers were taught entrepreneurial skills to sell the Mucuna products to earn incomes.

\section{Results and Discussions}

\section{Effect of Mucuna intercrop on maize yield}

Mucuna cover cropping was introduced to farmers in Western Kenya counties - Bungoma,Kakamega and Siaya to solve problem of soil erosion and infertility. It was a project by GIZ-funded by German government. It was originally proposed to farmers for soil fertility improvement on poorly degraded soils. A survey was conducted during the 2014 growing season of 20 farmers who were exposed to the technology over a period of five years. The results showed that 50 percent of the participating farmers used the technology for at least three consecutive years. At first, the technology met a lot of resistance but later, after seeing the increase in the maize yields from the fields that had Mucuna, many farmers picked up the practice [3]. The maize yield increased from 5bags 
per acre to 60bags per acre in the fifth year of practice (Figure 1). This result is comparable with what was found in other parts of the world. According to Jonathan et al [2], use of Mucuna interventions in agro-systems revitalized land by improving soil fertility for crop cultivation. As nitrogen-fixing legume, it was reported to improve maize yield by between $200 \mathrm{~kg}$ and $800 \mathrm{~kg} /$ acre after a one-year fallow [11]. As cover crop, mucuna has a positive effect on soil moisture retention [12] and hence yield increase. Conclusions about the future viability of mucuna cover cropping may be drawn from an economic analysis based on some of the yield and adoption data. It indicated that positive returns are achieved at farmer levels in the second year after adopting mucuna. It was observed that adoption of mucuna saves the farmer from using organic fertilizers as the soils become fertile.

\section{Maize yield in subsequent years with Mucuna intercrop}

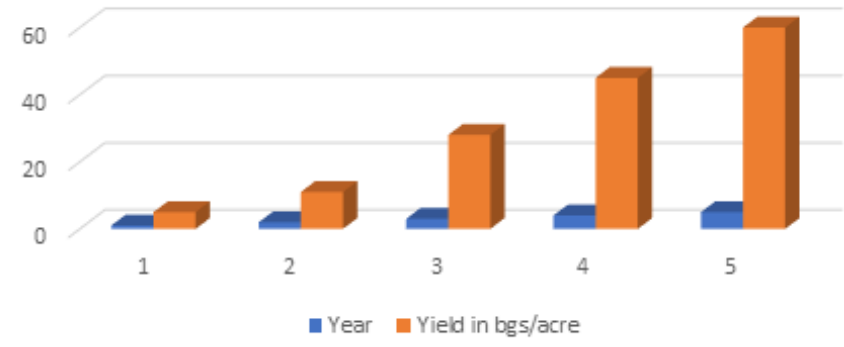

Figure 1: Maize yield in subsequent years with Mucuna intercrop

\section{Uses of Mucuna (Food and Nutrition Security)}

Mucuna has three main uses: food, feed (forage and seeds) and environmental management - cover crop and green manure [13]. It is used as a coffee substitute [14]. The Mucuna showed good potential to do well in a stressed environment and low soil fertility that does not allow most other food legumes. It is suitable in intercropping systems [15], especially in Western Kenya, where maize is staple crop, plus millet, sorghum and sugarcane. Mucuna vines and foliage can be used as pasture, hay or silage while pods and seeds can be ground into a meal and fed to livestock [16].

In humans, Mucuna benefits are known to boost testosterone and libido, improve mood and increase energy. Mucuna pruriens protects the brain by keeping cognitive and neural functions in check, Mucuna pruriens is one of the more potent mood enhancing and libido stimulating superfoods available, with noticeable health benefits and a long list of uses. Balances stress and relaxes the brain, Facilitates healing of chronic wounds. The plants are used in herbalism against a range of conditions: urinary tract, neurological and menstruation disorders, constipation, edema, fevers, tuberculosis, ulcers, Helminthiases like elephantiasis and diabetes [17]. Mucuna pruriens (Velvet bean) is one of the most important sources of L-dopa, a common component of nootropics ("smart drugs"); it also contains serotonin, 5-HTP, nicotine, and some decidedly psychoactive compounds.

\section{Home processed Mucuna beans recipes}

Extension staff from wards that had large acres under mucuna of the county were trained on processing and utilization of Mucuna [10]. This enabled them to effectively guide the lead farmers during on - farm trainings within groups. The training content focused on processing methods, nutritive value, development of various recipes and utilization of Mucuna products. Entrepreneurial skills, market linkages and networking, among others [18]. This was followed by onfarm training of lead farmers on processing and utilization of Mucuna. This training targeted individual farmers and farmer groups involved in Mucuna production who were drawn from subcounties. A Face to Face or Farmer to Farmer(F-F) model of on-farm training was adopted for effective understanding. Herein are some of the recipes which were developed, tasted and adopted.

\section{General method of removing anti-nutritional factors at home}

1. Sort out and clean the harvested dried Mucuna beans.

2. Soak for 24 hours while changing water 3 times

3. Boil for 4 to 5 hours as you frequently change the water.

4. $\quad$ De-husk the beans (Husks can be fed to livestock while cotyledon for human)

5. The beans can be dried and can be used in various ways:
a) Boiled together with other foods
b) Milled into flour
c) Roasted until brown or dark brown then milled into powder- beverage

\section{Mucuna Recipes}

Trainees were divided into groups and developed various products, ranging from Mucuna Beverage, Mucuna/ wheat flour cake, Mucuna ugali(maize/millet), Mucuna - banana relish, Mucuna- potato mash, Mucuna-Maize dish, Mucuna / wheat flour Chapati, Mucuna mandazi, Mucuna pilau, crackies, Nutri porridge, cakes (Figure 2). 


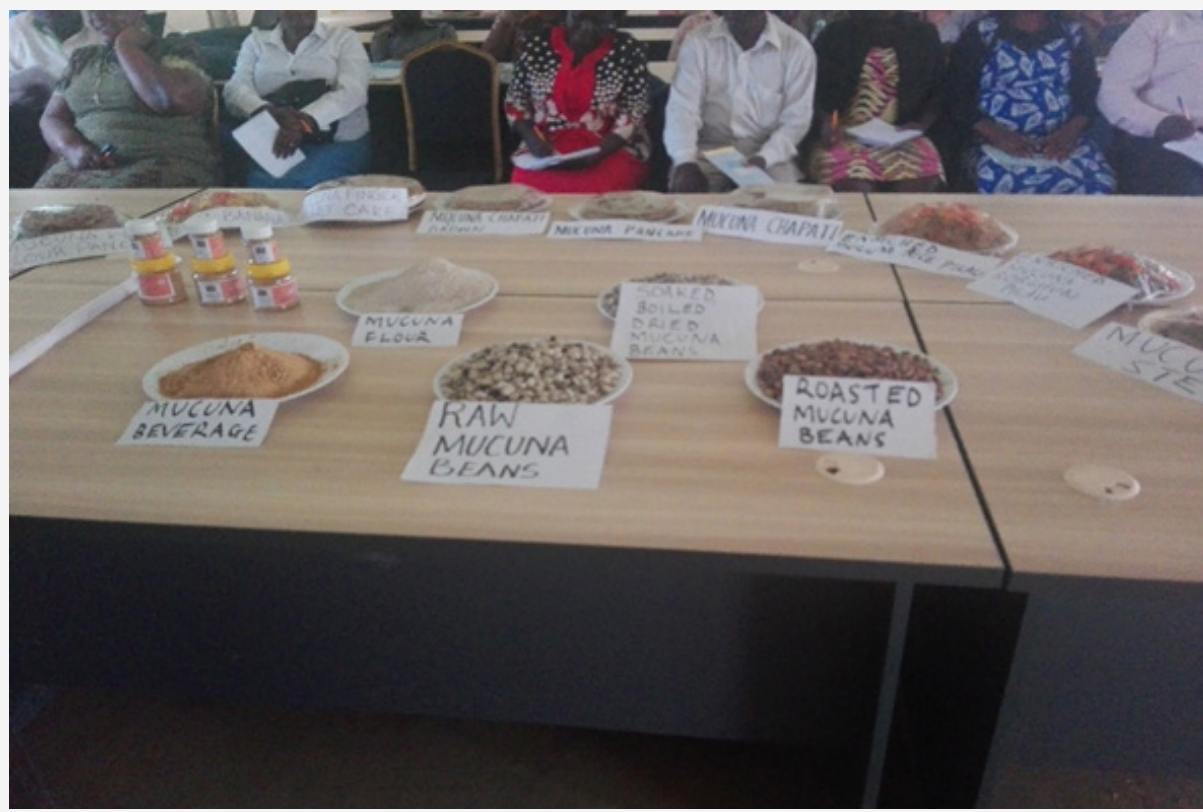

Figure 2: Mucuna home processed products.

\section{Mucuna crackies (Figure 3)}

\section{Ingredients}

Mucuna flour: 1 cup

Wheat flour: 3 cups

Sugar: 4 tbs

Margarine: 4tbs heaped

Salt to taste Cooking oil: just enough for deep fry

Mixed Spices: 2tbs water to make the dough

\section{Method}

- Mix all the dry ingredients in a bowl

- $\quad$ Add margarine, water and knead to make the dough

- $\quad$ Squeeze the dough through the noddle machine onto the hot oil

- $\quad$ Remove when golden brown

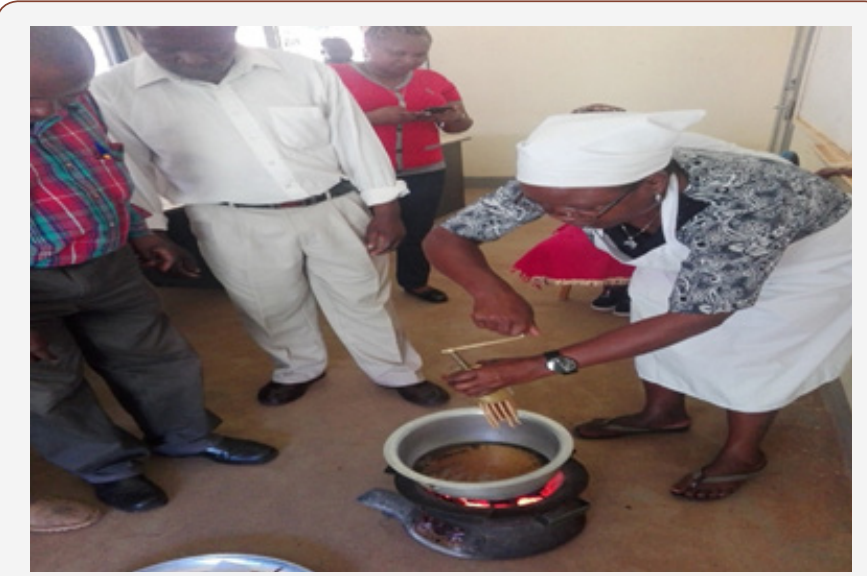

Figure 3: Dr Stella demonstrates on making Mucuna crackies.

\section{Mucuna Stew}

\section{Ingredients}

$1 \mathrm{~kg}$ dehusked Mucuna beans

Cooking salad

Spices

Onions and tomatoes

\section{Method}

- Boil the beans until soft.

- Blend the beans to make a thick puree.

- $\quad$ Fry onions add tomatoes and spices then add the beans.

- Continue to boil while stirring till it's ready.

- $\quad$ Serve with rice, chapatti or sweet potatoes

\section{Mucuna Chapati (Figure 4)}

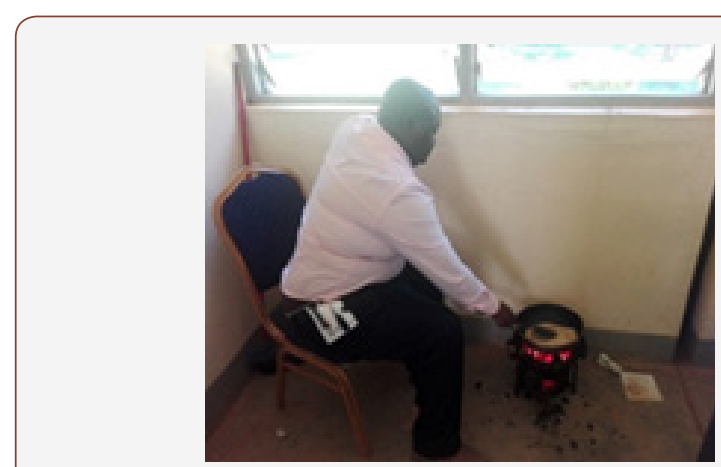

Figure 4: Panfrying Mucuna chapati.

\section{Ingredients}

Mucuna flour: 1 cup

Wheat flour: 3cups 
Cooking salad oil and Salt to taste

\section{Method}

- $\quad$ Add 1cup mucuna flour to 3 cups wheat flour.

- $\quad$ Add a little salt to taste

- $\quad$ Kneed the mixture to make chapatti dough

- $\quad$ Cook as we cook chapatti

\section{Mucuna Mash (Mafuke)}

\section{Ingredients}

6 medium size sweet potato

1cups boiled dehusked Mucuna beans

2 bunches of pumpkin leaves (optional)

1 teaspoon of margarine

Salt to taste

\section{Method}

4. Peel potatoes and chop into small pieces

5. Add to boiled dehusked Mucuna beans and salt to taste

6. Boil till all the food staffs are well cooked

7. Drain excess water, add margarine and mash to a smooth texture

8. Serve when hot with sour milk or fresh fruit juice

\section{Mucuna Bean Beverage (Figure 5)}

\section{Ingredients}

Dry Mucuna beans

\section{Method}

- $\quad$ Sort out and clean the dry Mucuna beans.

- $\quad$ Soak for 24 hours while changing water 3 times

- $\quad$ Boil for 2 to 3 hours as you frequently change the water

- Drain the water and dry in the sun

- Pan roast the beans until dark brown (or if Electric roaster, set at Temp- $150^{\circ} \mathrm{C}$ for 50 minutes)

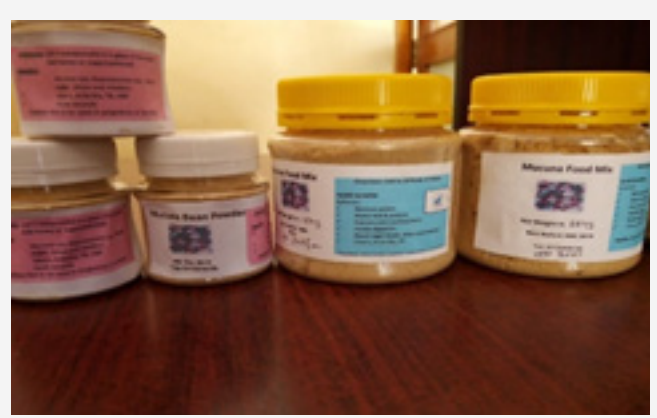

Figure 5: Mucuna beverage and food mix, bottled ready for market.

\section{Mucuna Food Mix}

Ingredients

Dry Mucuna beans

\section{Method}

- Sort out and clean the dry Mucuna beans.

- $\quad$ Soak for 24 hours while changing water 3 times

- Boil for 2 to 3 hours as you frequently change the water three times.

- Drain the water and dry in the sun

- $\quad$ Pan roast the beans until brown (or if electric roaster, set at Temp- 150 o C for 25 minutes)

- Grind into fine powder/flour (this can be used to enrich other foods)

- Mix the flour with any food additive of your choice and this can be used to thicken soups

\section{Mucuna as an Income Generating Activity (IGA)}

Farmers adopting mucuna cover cropping benefited from higher yields of maize with less labour for weeding. Many of the early adopters also earned additional revenue by selling Mucuna seed as the technology was disseminated. Some farmers after the training, picked up processing the Mucuna powder which is used as a beverage for sale. Due to its medicinal value and health benefits, Mucuna beverage sells like hot cakes in the region and it generates income to the families.

\section{Conclusion and Recommendations}

Mucuna beans like any other legume is a rich source of proteins and therefore can supplement proteins in the diet. Mucuna can be a source of income to households and hence improve livelihoods. Soil nutrient management should thus be integrated with mucuna residue supplemented with moderate amounts of inorganic fertilizer for high crop yields. Mucuna fallowing has additional benefits, such as soil erosion control and maintenance or improvement of the soil's physical, chemical and biological properties. Mucuna beans should be adopted for soil rehabilitation, food and nutrition security and income generation.

\section{Acknowledgement}

I acknowledge the Germany Cooperation for funding the project in Kenya, the Ministry of Agriculture, County Government of Bungoma for providing staff to participate in the survey.

\section{Conflict of Interest}

None.

\section{References}

1. Food and Organization (2011) Grassland Index. A searchable catalogue of grass and forage legumes. FAO, Rome, Italy.

2. Jonathan NH, Philip A, John LT, Otuo Akyampong B, Patrick A (2015) The Potential and Coupling Effect of Compost and Mucuna for Quarry Site 
Restoration: A Study at the Yongwa Limestone Quarry in Ghana. Applied Ecology and Environmental Sciences 3(2): 30-35.

3. Ministry of Agriculture Annual report (2018) county Government of Bungoma, Kenya.

4. Kenya Agricultural Research Institute (2014) Report of Soil suitability evaluation for maize production in Kenya. A report by National Accelerated Agricultural Inputs Access Program (NAAIAP) in collaboration with Kenya Agricultural Research Institute (KARI, now KALRO). Department of Kenya Soil survey.

5. Liener IE (1994) Implications of antinutritional components in soybean foods. Crit Rev Food Sci Nutr 34(1): 31-67.

6. Alonso R, Aguire A, F Marzo (2000) Effects of extrusion and traditional processing methods on antinutrients and in vitro digestibility of protein and starch in faba and kidney beans. J Food Chem 68(2): 159-165.

7. Duke JA (1981) Handbook of Legumes of World Economic Importance. Plenum Press: New York, USA, 170-173.

8. Mary Stella Wabwoba, Jacob Wanambacha Wakhungu, Stanley Omuterema (2015) Household Food Insecurity Coping Strategies in Bungoma County, Kenya.

9. Mugendi JB, Njagi ENM, Kuria EN, Mwasaru MA, Mureithi JG, et al. (2010) Effects of processing methods on the protein quality of mucuna bean (mucuna pruriens l). AJFAND 10(4).

10. Wabwoba MS, Emuria ME (2018) Conservation Agriculture and mucuna processing training report conducted at Mabanga Agriculture training Centre, Bungoma Kenya.
11. International Livestock Research Institute (2004) Sustainable croplivestock production for improved livelihoods and natural resource management in West Africa. Proceedings of an international conference held at the International Institute of Tropical Agriculture (IITA) Ibadan, Nigeria, 19-22.

12. Buckles D, Triomphe B, Sain G (1998) Cover crop in hillside agriculture: farmer innovation with Mucuna. IDRC/CIMMYT.

13. Heuzé V, Tran G, Hassoun P, Renaudeau D, Bastianelli D (2015) Velvet bean (Mucuna pruriens). Feedipedia, a programme by INRA, CIRAD, AFZ and FAO, Rome, Italy.

14. Eilittä M, Carsky RJ (2003) Efforts to improve the potential of Mucuna as a food and feed crop: background to the workshop. Trop. Subtrop. Agroecosyst 1: 47-55.

15. Cook BG, Pengelly BC, Brown SD, Donnelly JL, Eagles DA, et al. (2005) Tropical forages. CSIRO, DPI\&F(QId), CIAT and ILRI, Brisbane, Australia.

16. Chikagwa Malunga SK, Adesogan AT, Sollenberger LE, Phatak SC, Szabo NJ, Kima, et al. (2009) Nutritional characterization of Mucuna pruriens. 4. Does replacing soybean meal with Mucuna pruriens in lamb diets affect ruminal, blood and tissue L-dopa concentrations? Anim Feed Sci Technol 148(2-4): 124-137.

17. Majekodunmi SO, Oyagbemi AA, Umukoro S,Odeku OA (2011) Evaluation of anti-diebatic properties of mucuna pruriens seed extract. Asian Pac J Trop Med 4(8): 632-636.

18. Wafar R J, Ademu LA, Kirfi YA, Shehu II (2016) Effect of Processing Methods on the Utilization of Mucuna Sloanei (Horse Eye Bean) Seed Meal by Broiler Chicken. British Journal of Applied Research 1(1): 00100014. 